ROCZNIKI TEOLOGICZNE

Tom LXVI, zeszyt 3 - 2019

DOI: http://dx.do.org/10.18290/rt.2019.66.3-10

JERZY GOCKO SDB

\title{
TEOLOGIA POLITYCZNA JOHANNA BATISTY METZA WOBEC KRYZYSU NAUKI SPOŁECZNEJ KOŚCIOŁA PO SOBORZE WATYKAŃSKIM II
}

\author{
JOHANN BATISTA METZ'S POLITICAL THEOLOGY AND THE CRISIS \\ OF THE SOCIAL DOCTRINE OF THE CHURCH \\ AFTER THE SECOND VATICAN COUNCIL
}

\begin{abstract}
A b s t r a c t. Theologians of the period of the Second Vatican Council, based on the theology of earthly realities, sought to remove the split between theology and life and to respond to the crisis of the social doctrine of the Church at that time. In this context a specific role was played by the political theology, with Johann Batista Metz as its main representative. The article shows and assesses political theology as a new model of the social doctrine of the Church.
\end{abstract}

Key Words: Political Theology; Johann Batista Metz; Jürgen Moltmann; Social Doctrine of the Church; Second Vatican Council.

Ostatnie lata przed Soborem przyniosły zmianę podejścia do nauki społecznej Kościoła. Nie brakowało głosów oznajmiających wyczerpanie się potencjału, jeśli nie kres katolickiej nauki społecznej. W wielu środowiskach katolickich, które doświadczyły bardzo negatywnych sądów, czy to z punktu widzenia historycznego czy teologicznego, odnośnie do chrześcijańskiej nauki

Prof. dr hab. JERZY Gocko SDB - kierownik Katedry Teologii Moralnej Społecznej na Wydziale Teologii KUL; adres do korespondencji: ul. Kalinowszczyzna 3, 20-129 Lublin; e-mail: Jerzy@Gocko.pl 
społecznej, rodziły się wątpliwości, czy zachowała ona jeszcze i w jakiej mierze swoją ważność, aktualność, atrakcyjność, czy raczej idzie tu o sprawę, która przeżyła się i której należy poniechać. W odpowiedzi na zaistniała sytuację zaczęto wypracowywać nowe jej modele. Szczególnym źródłem inspiracji w tym zakresie okazały się teologie rzeczywistości ziemskich. Przedmiotem niniejszego studium jest ukazanie i ocena wypracowanej na jej kanwie przez Johanna Batistę Metza teologii politycznej jako propozycji nowego modelu nauki społecznej Kościoła.

\section{NAUKA SPOŁECZNA KOŚCIOŁA DOBY SOBORU: OD EKSPANSJI DO KRYZYSU}

Druga połowa XIX wieku to okres stopniowego rozwoju katolickiego ruchu społecznego zwieńczonego wydaniem w 1891 roku przez Leona XIII pierwszej encykliki społecznej Rerum novarum. Wydarzenia te przyczyniły się niewątpliwie do wzmożenia różnorodnych pozytywnych procesów, mających na celu nie tylko większe otwarcie się Kościoła na świat oraz odczytanie jego właściwego miejsca pośród rzeczywistości doczesnych, ale także pogłębione zaangażowanie społeczne Kościoła. Szeroko rozumianemu ruchowi chrześcijańsko-społecznemu oraz podejmowanemu posłannictwu Kościoła w świecie, uwzględniającemu zarówno jego podstawowy - nadprzyrodzony - wymiar, jak również ściśle z nim związany aspekt społeczny, towarzyszyła rozwijana przez wiele ośrodków naukowych refleksja teologiczna, dla której ważnym przyczynkiem i zarazem dopełnieniem były także liczne enuncjacje Magisterium Ecclesiae. Miała ona na celu z jednej strony ułatwić zrozumienie specyfiki tego posłannictwa, tym bardziej, że niektóre formy jego praktycznej realizacji niewiele różniły się od aktywności, jaką przejawiały inne świeckie ruchy społeczne, z drugiej zaś była impulsem do dalszego rozwoju tegoż posłannictwa.

W wymiarze doktrynalnym apogeum jej rozwoju stała się opublikowana rok przed rozpoczęciem Soboru Watykańskiego II przez św. Jana XXIII encyklika Mater et Magistra. Wizja nauki społecznej, w niej ukazana, jawiła się jako zwarty system, o jasno zarysowanym przedmiocie oraz konturach metodologicznych, bazująca w aspekcie epistemologicznym na filozofii i prawie naturalnym. Encyklika potwierdziła także aktualność dotychczasowej nauki społecznej Kościoła: ,jest zawsze aktualna” (perpetua vi pollet) oraz podejmuje próbę jej instytucjonalizacji poprzez wezwanie: „by była ona wykładana jako przedmiot obowiązkowy w szkołach katolickich wszelkiego rodzaju 
i stopnia, a najbardziej oczywiście w seminariach duchownych [...]; by ta nauka o sprawach społecznych była włączona w program nauki religii, prowadzonej w parafiach oraz w zrzeszeniach apostolstwa katolików świeckich"1.

Encyklika była owocem prężnego rozkwitu inicjatyw i ruchów chrześcijańsko-społecznych, dzieł miłosierdzia oraz stowarzyszeń przykościelnych, sięgającego encykliki Quadragesimo anno Piusa XI. Kluczową rolę w tym względzie odegrała powstała na początku XX wieku Akcja Katolicka, w której wiele uwagi poświęcono problematyce chrześcijańsko-społecznej i to nie tylko w wymiarze konkretnego zaangażowania, ale także pod kątem formacyjnym. Nauka społeczna Kościoła była w tym czasie motywacją do działania i włączenia się w przekształcanie struktur społecznych, politycznych i gospodarczych również dla wielu polityków i działaczy społecznych. Sukcesy odwołujących się bezpośrednio do niej stronnictw chadeckich zdawały się być sprawdzianem jej ważności i aktualności. Chrześcijańsko-demokratyczni mężowie stanu, tacy jak Konrad Adenauer, Alcide De Gasperi czy Robert Schuman, stworzyli fundamenty współczesnej Europy, kierując się właśnie inspiracjami chrześcijańskimi płynącymi ze społecznego nauczania Kościoła. Wiara chrześcijańska oraz przesłanie Ewangelii były dla nich źródłem opcji intelektualnych i politycznych wyborów ${ }^{2}$.

Pomijając szczegółowe analizy dotyczące pierwszego okresu rozwoju katolickiej nauki społecznej, bo nie jest to przedmiotem niniejszego studium, należy stwierdzić, że do lat sześćdziesiątych nauka społeczna Kościoła była chlubą, a nade wszystko źródłem, do którego nawiązywały programy wielu pokoleń katolików, pragnących zaangażować się w życie polityczne i społeczne celem stworzenia ustroju bardziej sprawiedliwego i ludzkiego.

Jednak, paradoksalnie, już ostatnie lata przed Soborem zapowiadały tendencje zupełnie przeciwne do wyżej opisanych, a nawet wzajemnie się wykluczające, które ostatecznie przyniosły całkowitą zmianę podejścia do nauki społecznej Kościoła. Okres swoistego apogeum rozwoju nauki społecznej Kościoła, połączony z ukonstytuowaniem się jej tożsamości metodologicznej na danym etapie rozwoju oraz podjęciem wysiłku jej instytucjonalizacji na obszarze badań naukowych i dydaktyki, scalił się z czasem, w którym coraz mocniej odzywały się głosy kwestionujące sens i potrzebę dalszego istnienia katolickiej nauki społecznej, czy to z racji teoretycznych, czy też ze względu

\footnotetext{
${ }^{1} \mathrm{Nr} 223$.

2 Por. Co dziś oznacza „nauka spoteczna Kościoła” (Przedruk z „La Civiltà Cattolica”), tłum. H. Czepułkowski, „Chrześcijanin w Świecie” 12(1980), nr 1, s. 34.
} 
na jej mniemaną nieprzydatność i nieskuteczność. Stanowiska te przyjmowały bądź to postać wyraźnych stwierdzeń afirmujących, bądź to stawały się przedmiotem hipotez, które próbowano następnie weryfikować. Weryfikacja ta nie zawsze przyjmowała postać solidnych badań odwołujących się do osiągnięć współczesnej eklezjologii i specyfiki nauki społecznej Kościoła. Zarzucając jej ideologizację, sama niekiedy przyjmowała postać argumentacji o nastawieniu ideologicznym, będącej wyrazem tendencji sekularyzacyjnych i laicyzujących, odmawiających Kościołowi prawa do obecności w przestrzeni społecznej. Uważano tym samym, że Kościół w końcu uwolni się od swoistej kuli u nogi, jaką była chrześcijańska nauka społeczna, zredukowana do ideologii konserwatywnej, a więc pewnego systemu poglądów wyrażających polityczne interesy Kościoła. Symptomatyczny w tym kontekście stał się tytuł eseju Marie-Dominique Chenu opublikowany w języku francuskim w 1979 r.: $L a$ doctrina sociale de l'Église? Ça n'existe pas ${ }^{3}$.

Trzeba w tym miejscu nadmienić, że w wielu środowiskach katolickich, które doświadczyły owych negatywnych sądów, czy to z punktu widzenia historycznego czy teologicznego, odnośnie do chrześcijańskiej nauki społecznej, rodziły się wątpliwości, czy zachowała ona jeszcze i w jakiej mierze swoją ważność, aktualność, atrakcyjność, czy raczej idzie tu o sprawę, która przeżyła się i którą należy poniechać ${ }^{4}$. Przyczyn tego stanu rzeczy było wiele i nie sposób je tu szerzej omówić. Rodzące się pytania i wątpliwości były ważne, chodziło w nich niejednokrotnie o to, czy sama idea doktryny społecznej Kościoła jest do pogodzenia z Ewangelią i chrześcijańską wizją życia.

Nie brakowało głosów, które główne przyczyny zaistniałej sytuacji umieszczały w szerszym kontekście, niż tylko w samych trudnościach metodologicznych omawianej dyscypliny. Ich autorzy uważali, że w katolickiej nauce społecznej znajdują odzwierciedlenie inne niepokojące zjawiska, dotykające swymi konsekwencjami całą teologię katolicką, takie jak: sekularyzacja, kryzys modelu Kościoła, trudności w określeniu proprium christianum w naukach kościelnych, rozróżnienie wymiaru ludzkiego i chrześcijańskiego w strukturze metodologicznej. Co więcej kryzys katolickiej nauki społecznej i podejmowane $\mathrm{w}$ związku $\mathrm{z}$ tym debaty stały się przedmiotem instrumentali-

\footnotetext{
${ }^{3}$ Pierwotny tekst został opublikowany w 1977 r. w języku włoskim pod tytułem: La dottrina sociale della Chiesa. Origine e sviluppo (Queriniana, Brescia 1977).

${ }^{4}$ J. Querejazu w swoim podziale rozwoju katolickiej nauki społecznej określa dekadę lat siedemdziesiątych jako fazę kryzysu tej dyscypliny („Peiiodo de crisis, che abarca la decada de los annos 70”). Por. La teologia moral social postvaticana. Genesis e instancias, „Moralia” 14(1992), s. 284-285.
} 
zacji. Dyskusje na temat nauczania społecznego Kościoła stały się dla niektórych nurtów w łonie Kościoła okazją do ataku lub obrony różnych opcji teologicznych i eklezjalnych ${ }^{5}$.

Zaistniała sytuacja stała się nowym wezwaniem dla teologii katolickiej. Choć Kościół swoje nauczanie społeczne rozumiał jako refleksję moralną nad zadaniami życia publicznego, która służy mu pomocą do wskazywania możliwych rozwiązań problemów w sposób respektujący ludzką godność, to jednak w odbiorze społecznym traktowane ono było jako ideologia. „W nauczaniu społecznym widziano bardziej trzecią drogę, niż jedną z form ewangelizacji i humanizacji świata, wytyczającą kierunki rozwoju życia społecznego między odrzucanym zdecydowanie przez Kościół kolektywizmem marksistowskim a liberalizmem, budzącym także wiele zastrzeżeń. Zbyt małe podkreślanie wyraźnego odniesienia nauczania i praktyki społecznej Kościoła do jego podstawowej, religijnej misji z jednej strony, było źródłem niezrozumienia istoty najgłębszego sensu jego zaangażowania $\mathrm{w}$ tym zakresie, $\mathrm{z}$ drugiej zaś, traktowanie działalności chrześcijańsko-społecznej przez działaczy w kategoriach walki politycznej nie pozwalało dostrzec religijnego znaczenia aktywności społecznej Kościoła"6.

W opozycji do tych negatywnych zjawisk w dobie Soboru dojrzewały ciekawe ujęcia eklezjologiczne, w tym nowe doświadczenie Kościoła jako Ludu Bożego, które pozwalały określić miejsce, jakie zajmuje on w historii, zarówno w stosunku do Ludu Starego Przymierza, którego jest kontynuacją, jak i w stosunku do całej ludzkości. Pozwoliły również określić jego miejsce wobec świata ${ }^{7}$. Połączeniu tajemnicy stworzenia z misterium odkupienia wraz $\mathrm{z}$ włączeniem się chrześcijan w przemianę świata towarzyszyło nowe spojrzenie na ten świat. Podjęto wysiłek wypracowania nowej syntezy między wiarą a zaangażowaniem $\mathrm{w}$ rzeczywistość doczesną ${ }^{8}$.

\footnotetext{
${ }^{5}$ Por. M. VIDAL, L'atteggiamento morale, t. 3: Morale sociale, Cittadella, Assisi 1981, s. $41-42$.

${ }^{6}$ P. NiteCKI, Rozpoznawać znaki nowych czasów. Nad przestaniem Jana Pawła II po Wielkim Jubileuszu Chrześcijaństwa, PAX, Warszawa 2002, s. 94.

7 Por. SoBÓR WATYKAŃSKI II, Konstytucja dogmatyczna o Kościele Lumen gentium, nr 9-13; T. SIKORSKI, Eklezjalno-sakramentalny charakter moralności chrześcijańskiej, „Ateneum Kapłańskie” 65(1973), t. 81, s. 103-105; S. OLEJNIK, Miejsce Ludu Bożego i znaków czasu w teologii moralnej, „Ateneum Kapłańskie” 65(1973), t. 81, s. 92-101.

${ }^{8}$ Por. B. HÄRING, Moraltheologie unterwegs, „Studia Moralia” 4(1966), s. 15.
} 


\section{TEOLOGIE RZECZYWISTOŚCI ZIEMSKICH}

To spotkanie świata w kontekście eklezjalnym i eschatologicznym zaowocowało po Soborze Watykańskim II rozwojem licznych teologii: rzeczywistości ziemskich, świata i doczesności wywodzących się wprawdzie z obszarów teologii dogmatycznej, fundamentalnej czy pastoralnej, lecz obejmujących swoim wpływem także teologię moralną. Były one rezultatem spotkania Kościoła ze światem, sprzężenia dwóch czasów: czasu zbawienia z czasem ziemskiej historii, wspólnoty eklezjalnej z konkretnym życiem. Na pewno szereg szczegółowych koncepcji z nimi związanych, które trudno tu szerzej rozpatrywać, może budzić wątpliwości i jest nie do pogodzenia z oficjalnym nauczaniem społecznym Kościoła. Jednak niemałą ich zasługą pozostaje wyczulenie współczesnej teologii na tętno czasu, na troskę o godność człowieka i autentyzm chrześcijaństwa. W teologiach tych należy docenić te wartości, jakimi powinna odznaczać się każda refleksja teologiczna, a więc uwydatnienie wspólnoty ludu eklezjalnego w zmierzaniu poprzez świat do pleroma Christi ${ }^{9}$.

Teologowie doby Soboru na kanwie teologii rzeczywistości ziemskich, poprzez swoje badania na temat gospodarki, techniki, pracy i działalności ludzkiej, czasu wolnego, przedsiębiorstwa przemysłowego, rewolucji, postępu ludzkiego, nadziei, laikatu, sekularyzacji i laicyzacji, pokoju, historii, materii, czy w końcu wyzwolenia, pragnęli objąć refleksją teologiczną całą rzeczywistość egzystencji człowieka, starali się usunąć rozłam, jaki panował między teologia i życiem. Wychodzili oni z założenia, iż wzajemna obcość między chrześcijaństwem, reprezentowanym przez Kościół, a światem poszukującym dróg do uporania się z własnymi problemami, przezwyciężyć można tylko przez skoncentrowanie się na Osobie Jezusa Chrystusa, który wszedł w ludzkie dzieje i jest centralnym punktem odniesienia $w$ relacjach między Bogiem a człowiekiem. Teologia ta w zamierzeniu ich twórców miała zatem umacniać związek chrześcijanina z Bogiem, który nie przeciwstawia się zaangażowaniu w sprawy tego świata, lecz nadaje mu głębszy, religijny, a więc także w pełni ludzki sens. Starała się ona być zakorzeniona $\mathrm{w}$ życiu wiernych uczestniczących $\mathrm{w}$ problemach świata i traktować je jako pytania stawiane pod adresem teologii, która ma pomagać w przeżywaniu wiary w doczesności ${ }^{10}$. Teologowie Kościoła,

\footnotetext{
${ }^{9}$ Por. J. KRUCINA, Spór między katolicka nauka spoteczna a teologia polityczna, „Collectanea Theologica” 42(1972), f. 2, s. 39-51; T. SIKORSKI, Wokót projektu teologii społecznej, w: W kierunku chrześcijańskiej kultury, red. B. Bejze, Wydawnictwo Sióstr Loretanek, Warszawa 1978, s. 101.

${ }^{10}$ Por. P. NiTECKI, Rozpoznawać znaki nowych czasów, s. 95-96.
} 
rozumianego jako sakrament zbawienia dla wszystkich ludzi, przyjęli wyzwanie, by otworzyć się na problemy, niepokoje i nadzieje świata ${ }^{11}$.

Battista Mondin, dokonując ich charakterystyki, czyni interesującą konstatację, iż nie należy ich interpretować jako formy teologii cząstkowych czy jako refleksji nad jakąś partykularną ludzką aktywnością w świetle Objawienia, ale jako teologie fundamentalne w tym znaczeniu, że określona ludzka działalność (polityka, praca, zabawa itp.) zostaje potraktowana jako narzędzie hermeneutyczne dla zrozumienia i wyrażenia prawdy objawionej ${ }^{12}$. W kontekście zanegowania dotychczasowego ujęcia katolickiej nauki społecznej opartej na tradycyjnym narzędziu hermeneutycznym, jakim była filozofia scholastyczna i prawo naturalne, nie trzeba było długo czekać, aby powyższy mechanizm został wykorzystany także przy wypracowaniu kolejnych alternatywnych koncepcji zajmujących jej miejsce.

Konfrontacja katolickiej nauki społecznej z teologiami świata i rzeczywistości ziemskich, pochodzących z innych działów teologicznej refleksji nad egzystencją człowieka w świecie, musiała prowadzić do problemu samoświadomości katolickiej nauki społecznej. Wyrażała się ona w próbach odpowiedzi na następujące lub podobne pytania: Czym jest katolicka nauka społeczna? Jak uzasadnia swoją obecność wobec mnogości teorii społecznych? Jak zintegrować jej deskryptywny i normatywny charakter? Skąd właściwie bierze się normatywność w odniesieniu do autonomicznych w punkcie wyjścia obszarów polityki, gospodarki, nauki, kultury? Gdzie jest miejsce na jej teologiczne ubogacenie?

Pytania te i wewnątrzkościelne nurty interpretujące rzeczywistość społeczną w dobie kryzysu dotychczasowego modelu nauki społecznej Kościoła oraz wynikające $\mathrm{z}$ nich prakseologiczne konsekwencje stwarzały w pierwszej fazie recepcji soborowej obraz pełnego sprzeczności pluralizmu. Ukazane próby teologizacji nauki społecznej Kościoła czy etyki społecznej najczęściej stawały się zarzewiem nowych debat i interpretacji. Wszystkie one zasadniczo wpisywały się w paradygmat nakreślony jeszcze w okresie przedsoborowym przez twórców teologii rzeczywistości ziemskich, którzy pragnęli objąć refleksją teologiczną całą rzeczywistość egzystencji człowieka, starali się usunąć rozłam, jaki panował między teologią i życiem, między wiarą a praxis. Teologie te w zamierzeniu ich twórców miały umacniać związek chrześcijanina

\footnotetext{
${ }^{11}$ Por. I. MroczKowsKi, Współczesny kontekst moralnego nauczania Kościoła, w: „Veritatis splendor”. Przestanie moralne Kościoła, red. B. Jurczyk, RW KUL, Lublin 1994, s. 20-21.

12 Por. Storia della Teologia, t. 4, Edizioni Studio Domenicano, Bologna, 1997, s. 701.
} 
z Bogiem, który nie przeciwstawia się zaangażowaniu w sprawy tego świata, lecz nadaje mu głębszy, religijny, a więc także w pełni ludzki sens. Starały się one być zakorzenione $\mathrm{w}$ życiu wiernych uczestniczących w problemach świata i traktować je jako pytania stawiane pod adresem teologii, która ma pomagać $\mathrm{w}$ przeżywaniu wiary $\mathrm{w}$ doczesności ${ }^{13}$.

Usiłowania te znalazły swoiste apogeum w teologii politycznej, sformułowanej i najpełniej opracowanej przez Johanna Batistę Metza. Wyrosła ona z jednej strony z przekonania o niemożności prostego przełożenia przesłania ewangelicznego na struktury i instytucje polityczne, z drugiej zaś z przeświadczenia, że przesłanie to $\mathrm{w}$ tym samym czasie ma do spełnienia bardzo konkretną i niezbędną rolę także w wymiarze życia ludzkiego. Jej zwolennicy uważaja, że Kościół winien złączyć swoje wysiłki ze światem, aby wspólnie znaleźć rozwiązanie najbardziej palących problemów ludzkości: głodu, niesprawiedliwości, rasizmu, pokoju itp. Jego wkład jednak powinien polegać nie tyle na szukaniu konkretnych rozwiązań strukturalnych, co raczej na weryfikacji istniejących i proponowanych modeli w oparciu o dokonaną wcześniej ich dokładną analizę ${ }^{14}$. Uprzedzając dalsze rozważania, trzeba już w tym miejscu stwierdzić, że tym, co będzie odróżniało teologię polityczną od nauki społecznej Kościoła, będzie m.in. właśnie owo kryterium, w oparciu o które owa weryfikacja ma się dokonać.

Metz w jednym ze swoich dzieł, w którym stworzył podstawy teologii politycznej, poddaje zdecydowanej krytyce zbyt indywidualistyczną, spirytualistyczną i nazbyt sprywatyzowaną interpretację, która w przeszłości cechowała przesłanie chrześcijańskie względem świata, i proponuje spojrzeć na Chrystusa jako na osobę publiczną, a w zbawieniu ludzkości wyróżnia wyraźny wymiar polityczny ${ }^{15}$. Zakładając charakter publiczny i społeczny Objawienia, podstawowe zadanie Kościoła upatruje w budzeniu sumień w rzeczywistości społecznej, która osadzona jest między dwiema osiami: nauczaniem Jezusa i rzeczywistością społeczno-polityczną tego świata. Autor precyzuje, że Kościół jest obecny w świecie i w historii jako instytucja profetyczno-krytyczna ${ }^{16}$.

\footnotetext{
${ }^{13}$ Por. P. NiteCKI, Rozpoznawać znaki nowych czasów, s. 95-96.

${ }^{14}$ Por. B. Mondin, La Chiesa, primizia del Regno. Trattato di ecclesiologia, EDB, Bologna 1986, s. 490.

${ }^{15}$ Por. Zur Theologie der Welt, Matthias-Grünewald-Verlag, Kaiser, Mainz-München 1968.

${ }^{16}$ Por. J.B. METZ, I rapporti tra la chiesa e il mondo alla luce di una teologia politica, w: Teologia del rinnovamento. Mete, problemi e prospettila della teologia contemporanea, red. V. Pagani, Cittadella, Assisi 1969, s. 268-277. Por. także: T. HerR, Wprowadzenie do katolickiej nauki społecznej, tłum. A. Mosurek, WAM, Kraków 1999, s. 62-64.
} 


\section{TEOLOGIA POLITYCZNA JAKO POSZUKIWANIE NOWEGO MODELU NAUKI SPOŁECZNEJ KOŚCIOŁA W ODPOWIEDZI NA ZAISTNIAŁY KRYZYS}

Metz od samego początku traktował teologię polityczną jako alternatywę wobec tradycyjnego ujęcia nauki społecznej Kościoła. Był przekonany, że koegzystencja Kościoła wewnątrz dzisiejszego społeczeństwa możliwa będzie jedynie w kontekście „,negatywnej dialektyki” Szkoły Frankfurckiej. Poprzez solidarność z wykluczonymi i ofiarami współczesności, a także dzięki przekształcaniu istniejących struktur bezprawia w duchu Ewangelii, Kościół ma być ostoją humanum. W tym aspekcie teologia polityczna nie odbiega znacząco od profetyczno-krytycznej funkcji nauki społecznej Kościoła. Kluczowa różnica pojawia się dopiero przy pytaniu o konieczne do odczytania owych niesprawiedliwych struktur narzędzia. Kościół w ramach swojej klasycznej nauki społecznej wypracował ,zasady sprawiedliwości i równości”, które niosą w sobie obiektywne kryteria oceny rzeczywistości społecznej (kryterium prawdy absolutnej, którą dysponuje) oraz zawierają w sobie określone postulaty o charakterze normatywnym. Głównym kryterium w tym kontekście jawi się prawda o człowieku odczytywana na płaszczyźnie prawa natury. Ujęcie to, będące właściwym jądrem nauki społecznej Kościoła, zostało przez Metza zakwestionowane jako nieadekwatne. Dotychczasowa nauka społeczna Kościoła wraz ze swoim teoriopoznawczym aparatem, odwołującym się do analizy społeczno-politycznej, filozoficzno-etycznego rachunku dóbr oraz teologicznej nauki o grzechu musi ustąpić miejsca nowemu dyskursowi. Jedynym źródłem poznania dla społecznej 'praxis' wyptywajacej $z$ wiary stanie się Ewangelia, a powstałe między nią a konkretnym działaniem „etycznospołeczne pęknięcie” zostanie uzupełnione bądź to dzięki analizie Szkoły Frankfurckiej, bądź to w przypadku powstałej za niedługo teologii wyzwolenia - analizie marksistowskiej ${ }^{17}$.

Sam Metz traktował swoją teologię polityczną jako „nową teologię polityczną", która przewyższa poprzednią jej fazę, za którą uważał dotychczasową naukę społeczną ${ }^{18}$. Samą tradycyjną naukę społeczną Kościoła postrzegał

${ }^{17}$ Por. L. Roos, Entstehung und Entfaltung der moderner Katholischen Soziallehre, w: Handbuch der Katholischen Soziallehre, red. A. Rauscher, Duncker\&Humblot, Berlin 2008, s. 118; W. OCKENFELS, Politik aus dem Glauben? Katholische Soziallehre und Politische Theologie, w: Christliche Gesellschaftslehre. Eine Ortbestimmung [3. Symposion zum Thema Kirche heute. Augsburg, 13-15 Oktober 1988], red. G. Baadte, A. Rauscher, Styria Verlag, Graz- Wien-Köln 1989, s. 134-136.

${ }^{18} \mathrm{Na}$ temat samego pojęcia nowej teologii politycznej Metza, a także jej rozwoju por. zbiór esejów jego autorstwa wydany w monografii Zum Begriff der neuen Politischen Theologie 1967-1997 (Matthias Grünewald Verlag, Ostfildern 1997). 
jako najbardziej zaangażowany element - wraz z neoscholastyką oraz tradycjonalizmem - apologicznego frontu Kościoła przeciw oświeceniu. Przy czym samo oświecenie traktował jako epokowy przewrót w historii chrześcijaństwa zarówno w dziedzinie teoretycznej (po raz pierwszy został postawiony problem tożsamości wiary chrześcijańskiej w obliczu rozumu), jak i praktycznej (rozbicie jedności między religią i społeczeństwem). Zadaniem nauki społecznej było przezwyciężenie owego pęknięcia między religia i społeczeństwem oraz przywrócenie jej na nowo społecznego wymiaru. Jednak - zdaniem Metza - ze względu na swój wsteczny charakter jest ona do tego niezdolna, co więcej porzuca problemy współczesnej filozofii, współczesne formy wiedzy i życia, oddzielając i izolując konsekwentnie myśl chrześcijańską od kultury, a samo chrześcijaństwo od społeczeństwa. Stąd, będąc kluczowym ogniwem frontu apologetycznego, ostatecznie wzmacnia tendencje, przeciw którym występuje: staje się czynnikiem usunięcia religii ze społeczeństwa ${ }^{19}$.

Metz pośrednio więc demaskuje naukę społeczną jako ideologię politycz$\mathrm{na}^{20}$. Nowa teologia polityczna wyrasta $\mathrm{w}$ istocie na gruzach frontu antyoświeceniowego, padłego pod naporem teologii sekularyzacji. Odtąd - według niego - zadaniem Kościoła nie jest już systematyczna nauka społeczna, która jest nie do przyjęcia w pluralistycznym świecie, lecz krytyka społeczna ${ }^{21}$. Metz w tym kontekście mówi nie tylko o prawie, ale wręcz o obowiązku wpływania teologii na praktyczną formację świata. Nie chodzi przy tym o teologiczne narzucanie przedmiotowo-konkretnych rozwiązań, które nie przekraczają granic rozumnej aktywności człowieka, lecz o podmiotową motywację tej aktywności. Celem krytycznej interwencji teologii jest stałe upominanie się o rozumność ludzkiego działania, by odpowiadało ono rozumianej integralnie naturze człowieka ${ }^{22}$.

\footnotetext{
${ }^{19}$ Relację teologii politycznej Metza oraz teologii wyzwolenia do nauki społecznej Kościoła omawia szeroko: G. COLOMBO, Nauka spoteczna a „teologie polityczne”, w: L. CASATI i in., Nauka społeczna Kościoła, tłum. S. Pyszka, WAM, Kraków 1998, s. 147-171.

${ }^{20}$ Taki sposób postrzegania nauki społecznej Kościoła dobrze oddaje jej określenie zaproponowane przez Wernera Kroha, ucznia Metza. Traktuje on nauczanie społeczne Kościoła jako: „,der kirchliche Versuch, der Entwicklung neuzeitlicher Gesellschaften ein eigenes, an mittelalterlichen Vorbildern orientiertes Gesellschaftsmodell entgegenzusetzen, die kirchlichen Ansprüche durch die Wiederherstellung einer voraufklärerischen Gesellschaft zur Geltung zu bringen und das moderne Freiheitsbewusstsein als unchrristlich und der wahren Freiheit des Menschen widersprechend zu entlarven" (Die Kirche im gesellschaftlichen Widerspruch, Kösel, München 1982, s. 16).

${ }^{21}$ Por. J.B. METz, Problem teologii politycznej a Kościót jako instytucja reprezentujaca wolność krytyki społecznej, tłum. J. Mierzwa, „Concilium” 1(1968), nr 1-10, s. 285-296.

${ }^{22}$ Postulat ten odpowiada koncepcji katolickiej nauki społecznej wyrażonej w encyklice
} 
Z perspektywy czasu widać, że zaproponował on nowe rozumienie nie tylko nauki społecznej, ale i chrześcijaństwa, zależne od zagadnień wynikających z przemian, jakie zaszły, oraz nakreślenia zarysów teologii zdolnej objąć społeczny i polityczny wymiar ludzkiego działania. Choć niewątpliwie Metz posunął się za daleko w swej teorii Kościoła jako instancji oceniającej społeczeństwo ludzkie, trudno jednak nie doceniać horyzontów, jakie otworzyła teologia polityczna wobec nauki społecznej Kościoła oraz jej roli w uświadomieniu sobie odpowiedzialności historycznej Kościoła wobec przyszłości człowieka i przeobrażenia społeczeństwa. Teologia ta nie była formą teologii upolitycznionej czy teologii polityki. Nie było jej celem usprawiedliwianie panujących idei czy absolutyzowanie określonych instytucji bądź form ustroju. Raczej należy ją uważać - w ujęciu całościowym - za nową koncepcję chrześcijańskiej moralności w świecie zsekularyzowanym. Jej przedmiotem materialnym była zbiorowa i zorientowana ku przyszłości aktywność ludzka budująca nowy świat, podczas gdy za przedmiot formalny należy przyjąć chrześcijańską nadzieję eschatologiczną, zobowiązującą wspólnotę kościelną do krytycznego zaangażowania się wraz z innymi w historyczny proces budowania świata ${ }^{23}$.

Metz na nowo postawił problem stosunku religii do rzeczywistości ziemskich. Zbyt długo trwająca w Kościele mentalność obronna przyczyniła się do tego, że zdrowy proces dojrzewania ludzi do postępu w dziedzinie doczesnej i do afirmowania autonomii rzeczywistości ziemskich połączony był nie tylko z dążeniem do likwidacji instytucji kościelnych, lecz także z negacja religijnego poglądu na świat. Odrzuca on tego typu postawę. Krytykuje tendencję współczesnej teologii do sprowadzania wiary chrześcijańskiej jedynie do sfery prywatności. Odwołując się do zapowiedzi Królestwa eschatologicz-

Sollicitudo rei socialis (nr 41). Jan Paweł II przyporządkowuje katolicką naukę społeczną do rzędu dyscyplin teologicznych, stwierdzając, że jej podstawowym celem jest wyjaśnianie złożonej rzeczywistości ludzkiej egzystencji w społeczeństwie i w kontekście międzynarodowym poprzez badanie jej zgodności czy niezgodności z nauką Ewangelii o człowieku i jego powołaniu doczesnym, a zarazem transcendentnym.

${ }^{23} \mathrm{Na}$ temat interpretacji teologii politycznej Metza i jej relacji do nauki społecznej Kościoła oraz teologii moralnej por. także: W. OCKENFELs, Politisierter Glaube? Zum Spannungsverhältnis zwischen Katholischer Soziallehre und Politischer Theologie, Institut für Gesellschaftswissenschaften, Bonn 1987; A. Bondolfi, Attorno alla „teologia politica” di J.B. Metz. Bilancio provvisorio di una proposta e di una discussione teologica in corso, „Rivista di teologia morale” 26(1975), s. 201-217; S. PRIVITERA, Alla luce del Vangelo e dell'esperienza umana. Un confronto metodologico della teologia morale con la teologia politica, „Rivista di teologia morale" 26(1975), s. 185-190; J. DE LA TORRE, La teología de un tiempo nuevo: la teología política, „Moralia” 5(1983), s. 465-487. 
nego, próbuje przezwyciężyć tę „prywatyzację" teologii, uważając, że przekaz chrześcijański, będący swego rodzaju orędziem publicznym, nie może być interpretowany wyłącznie w odniesieniu do kategorii egzystencjalnych i personalistycznych. Ma on także swój wymiar polityczny, to znaczy skierowany jest do wspólnoty jako takiej, implikując wezwanie do odpowiedzialności społecznej i politycznej, do zaangażowania mającego na celu budowę przyszłości. Pod wpływem nadziei eschatologicznej człowiek wierzący przechodzi z płaszczyzny kontemplacji na płaszczyznę działania przemieniającego rzeczywistości ziemskie. Pozytywne zadanie teologii politycznej, jak pisze w jednej ze swych książek Metz: „zmierza do określenia nowego rodzaju stosunków między religią a społeczeństwem, między Kościołem a rzeczywistością publiczną i społeczną, między wiarą eschatologiczną a praktyką społeczną"24.

\section{POZAKATOLICKIE UJECIA TEOLOGII POLITYCZNEJ}

Wysiłki na rzecz stworzenia teologii politycznej (w znaczeniu społecznej, odnoszącej się do spraw publicznych) podejmowane były także w obrębie protestantyzmu. Do najwybitniejszych przedstawicieli społeczno-politycznego nurtu współczesnej protestanckiej myśli teologicznej należą m.in. Jürgen Moltmann oraz Wolfhart Pannenberg. Obaj postulują uwzględnienie niezbędnej konwergencji porządku doczesnego i porządku nadprzyrodzonego, historii zbawienia i historii świata, w świetle której apologia Kościoła jest równocześnie apologią świata. Dzieje się tak dlatego, ponieważ doświadczalny świat jest jednym z komponentów eklezjalnej rzeczywistości. Różnorodne problemy współczesnego świata (sprawiedliwość, ekologia, pokój, terroryzm itd.) są w pewnym sensie także problemami eklezjologicznymi. Nieporozumieniem w tym kontekście są twierdzenia postulujące powściągliwość Kościoła w rozwiązywaniu tych problemów i ograniczające posłannictwo Kościoła jedynie do aspektów duszpasterskich, tym bardziej, że symptomy kryzysu tego duszpasterstwa są równocześnie symptomami kryzysu życia praktyczno-społecznego, odkrywanymi w aktualnym kontekście kulturowym (relatywizm poznaw-

${ }^{24}$ Zur Theologie der Welt, s. 13. Por. także: C. STRZESZEWSKI, Spoteczno-krytyczna funkcja katolickiej nauki społecznej, „Chrześcijanin w Świecie” 11(1979), nr 11, s. 4-5; E. ChiavacCI, Teologia politica, „Rivista di teologia morale” 4(1969), s. 13-34; J. DE LA TORRE, Nuevos supuestos metodológicos de la teología política, „Studia Moralia” 12(1974), s. $183-256$. 
czy i etyczny, marginalizacja, anonimowość, różne formy alienacji) ${ }^{25}$. W tym kontekście postuluje się ponowne przemyślenie społeczno-wyzwalającej funkcji Kościoła. Celem tego namysłu winno być nie tyle stworzenie wiarygodnej teorii, co raczej ożywionej nadzieją nowej, otwartej na uniwersalną współpracę praktyki Kościoła. Priorytet w tej współpracy ma wspólna troska o człowieka, usuwająca praktyczne zagrożenia jego historycznej egzystencji ${ }^{26}$.

Założenia nowej teologii politycznej dobrze oddaje dzieło Moltmanna Der gekreuzigte Gott ${ }^{27}$, w którym przypisuje on teologii funkcję krytyczną. Jej zadaniem pozostaje wykazywanie ograniczeń rozumu ludzkiego we wszystkich jego przejawach: w religii, polityce, ekonomii, nauce, życiu społecznym itd. Instrumentem pomocnym w realizacji tego zadania pozostaje Krzyż, jako fundament i punkt odniesienia dla funkcji krytycznej teologii chrześcijańskiej. Moltmann zdecydowanie odsłania zdradę chrześcijaństwa popełnianą przez tych, którzy redukują go do jakiejś formy filantropii, socjalizmu czy psychoanalizy. Chrześcijaństwo jest czymś zdecydowanie innym, co potwierdza najpełniej misterium Krzyża, z czym nie mogą się pogodzić ambicje przedstawicieli polityki, nauki i techniki ${ }^{28}$.

Koncepcje Metza, a także i przywołanego w ostatniej części Moltmanna niewątpliwie zasiały ferment w myśli etycznospołecznej okresu posoborowego i wywołały szereg polemik. Należy im zarzucić przede wszystkim to, że obie koncepcje usiłowały interpretować całość Objawienia wyłącznie w kluczu polityki lub eschatologii ${ }^{29}$. Jednak ich wkład w interpretację stosunku Koś-

\footnotetext{
${ }^{25}$ Por. J. CuDA, Praktyczno-społeczne kryterium wiarygodności objawionego sensu historii. Analityczno-syntetyczne studium inspirowane paradygmatem nowej teologii politycznej, Księgarnia Św. Jacka, Katowice 1999, s. 216.

${ }^{26}$ Por. J.B. Metz, J. Moltmann, W. Oelmüller, Kirche im Prozess der Aufklärung. Aspekte einer neuen ,politischen Theologie”, Matthias-Grünewald-Verlag, Kaiser, Mainz-München 1970, s. 67; J.B. METZ, Religion und Revolution, „Neues Forum” 14(1967), s. 464.

${ }^{27}$ Por. Der gekreuzigte Gott. Das Kreuz Christi als Grund und Kritik christlicher Theologie, Gütersloher Verlagshaus, München 1972.

${ }^{28}$ Por. B. Mondin, La Chiesa, primizia del Regno, s. 492.

29 Jacek Bartyzel w szerokiej typologii różnych znaczeń teologii politycznej koncepcję nowej teologii politycznej Metza traktuje jako przejaw modernistycznej teologii politycznej, która ideologizuje w duchu immanentyzmu treści eschatologiczne objawienia, takie jak wol-
} 
cioła do świata jest na pewno istotny, aczkolwiek domaga się głębszych analiz dotyczących specyfiki samej natury Kościoła i świata. Zwłaszcza u Moltmanna widać raczej przesadny nacisk na funkcję krytyczną ze stratą dla zaangażowania w świecie, choć po przesycie inkarnacjonizmem w latach sześćdziesiątych pewna zmiana akcentów była zrozumiała ${ }^{30}$.

Postawiona w centrum dyskursu krytyczna funkcja Kościoła, będąca konsekwencją interpretacji Objawienia w kontekście politycznego zaangażowania chrześcijan i samego Kościoła, na pewno ma ważną rolę do spełnienia, potwierdza to zresztą rozumienie katolickiej nauki społecznej zaproponowane przez Jana Pawła II, która według niego winna mieć przede wszystkim charakter profetyczno-krytyczny ${ }^{31}$. Funkcja krytyczna Kościoła wobec świata pozwala mu także zachować konieczny dystans względem niego, co prowadzi w konsekwencji do bycia znakiem sprzeciwu zwłaszcza wobec wszelkich redukcjonizmów i alienacji ${ }^{32}$.

Kościół nie może się jednak zadowolić samą krytyką. Jego wkład musi mieć także charakter konstruktywny i pozytywny. Musi być czujny wobec tego, co dzieje się na arenie świata, ale także włączać się odważnie w rozwiązywanie jego palących problemów. Kierowany Słowem Bożym i Duchem Świętym oraz inspirowany istotnymi elementami własnej nadprzyrodzonej kultury jest w stanie zaproponować różnego rodzaju nowe rozwiązania, prawa, instytucje, struktury i obyczaje, które przyczynią się do zapanowania w tym świecie Królestwa większej sprawiedliwości, braterstwa, zgody, solidarności, dobrobytu i szczęścia. Zwolennicy teologii politycznej podkreślają także, że Kościół nie może się zadowolić jedynie krytyką świata, niejednokrotnie tę samą krytykę musi odnieść do samego siebie, co uwyraźnił zdecydowanie Sobór Watykański II.

ność, pokój czy sprawiedliwość. Por. Teologia polityczna, w: Encyklopedia „biatych plam”, t. 17, red. M. Korytkowska i in., POLWEN, Radom 2006, s. 136.

${ }^{30}$ Por. S. DIANICH, La missione della chiesa nella teologia recente, w: Associazione Teologica Italiana: Coscenza e missione di Chiesa [Atti del VII Congresso nazionale dell'ATI], Cittadella, Assisi 1977, s. 166-175.

${ }^{31}$ Por. Jan PAWEe II, Encyklika Sollicitudo rei socialis, $\mathrm{nr} 41$.

32 Por. J. Gocko, Nauka społeczna Kościoła w poszukiwaniu własnej tożsamości, Towarzystwo Naukowe Franciszka Salezego, Warszawa 2013, s. 290-307. 


\section{BIBLIOGRAFIA (wybór)}

BARTYZEL J., Teologia polityczna, w: Encyklopedia „białych plam”, t. 17, red. M. Korytkowska i in., POLWEN, Radom 2006, s. 133-137.

Bondolfi A., Attorno alla „teologia politica” di J. B. Metz. Bilancio provvisorio di una proposta e di una discussione teologica in corso, „Rivista di teologia morale” 26(1975), s. 201-217.

Chenu M.-D., La dottrina sociale della Chiesa. Origine e sviluppo, Queriniana, Brescia 1977.

Co dziś oznacza „nauka społeczna Kościoła”. (Przedruk z „La Civiltà Cattolica”), tłum. H. Czepułkowski, „Chrześcijanin w Świecie” 12(1980), nr 1, s. 34-47.

Colombo G., Nauka społeczna a „teologie polityczne”, w: L. CASATI i in., Nauka społeczna Kościoła, tłum. S. Pyszka, WAM, Kraków 1998, s. 147-171.

CUDA J., Praktyczno-społeczne kryterium wiarygodności objawionego sensu historii. Analityczno-syntetyczne studium inspirowane paradygmatem nowej teologii politycznej, Księgarnia Św. Jacka, Katowice 1999.

DE LA TORRE J., La teología de un tiempo nuevo: la teología política, „Moralia” 5(1983), s. $465-487$

DiANICH S., La missione della chiesa nella teologia recente, w: Associazione Teologica Italiana: Coscenza e missione di Chiesa. [Atti del VII Congresso nazionale dell'ATI], Cittadella, Assisi 1977, s. 137-206.

KRUCINA J., Spór między katolicką nauką społeczną a teologią polityczną, „Collectanea Theologica" 42(1972), f. 2, s. 39-51.

Metz J.B., Moltmann J., Oelmüller W., Kirche im Prozess der Aufklärung. Aspekte einer neuen ,politischen Theologie”, Matthias-Grünewald-Verlag, Kaiser, Mainz-München 1970.

METZ J.B., I rapporti tra la chiesa e il mondo alla luce di una teologia politica, w: Teologia del rinnovamento. Mete, problemi e prospettila della teologia contemporanea, red. V. Pagani, Cittadella, Assisi 1969, s. 268-277.

MetZ J.B., Zum Begriff der neuen Politischen Theologie 1967-1997, Matthias Grünewald Verlag, Ostfildern 1997.

MetZ J.B., Zur Theologie der Welt, Matthias-Grünewald-Verlag, Kaiser, Mainz-München 1968.

Moltmann J., Der gekreuzigte Gott. Das Kreuz Christi als Grund und Kritik christlicher Theologie, Gütersloher Verlagshaus, München 1972.

Moltmann J., Der gekreuzigte Gott. Das Kreuz Christi als Grund und Kritik christlicher Theologie, Gütersloher Verlagshaus, München 1972.

Mondin B., La Chiesa, primizia del Regno. Trattato di ecclesiologia, EDB, Bologna 1986.

Mondin B., Storia della Teologia, t. 1-4, Edizioni Studio Domenicano, Bologna 1996-1997.

NiteCKI P., Rozpoznawać znaki nowych czasów. Nad przesłaniem Jana Pawła II po Wielkim Jubileuszu Chrześcijaństwa, PAX, Warszawa 2002.

OCKENFELS W., Politik aus dem Glauben? Katholische Soziallehre und Politische Theologie, w: Christliche Gesellschaftslehre. Eine Ortbestimmung. [3. Symposion zum Thema Kirche heute. Augsburg, 13-15 Oktober 1988], red. G. Baadte, A. Rauscher, Styria Verlag, GrazWien-Köln 1989, s. 131-145.

OCKENFELS W., Politischer Glaube? Zum Spannungsverhältnis zwischen Katholischer Soziallehre und politischer Theologie, Institut für Gesellschaftswissenschaften, Bonn 1987.

PRIVITERA S., Alla luce del Vangelo e dell'esperienza umana. Un confronto metodologico della teologia morale con la teologia politica, RvTM 26(1975), s. 185-190.

QUEREJAZU J., La teología moral social postvaticana. Génesis e instancias, „Moralia” 14(1992), s. 261-294. 
Roos L., Entstehung und Entfaltung der moderner Katholischen Soziallehre, w: Handbuch der Katholischen Soziallehre, red. A. Rauscher, Duncker\&Humblot, Berlin 2008, s. 103-124. VIDAL M., L'atteggiamento morale, t. 3: Morale sociale, Cittadella, Assisi 1981.

\title{
TEOLOGIA POLITYCZNA JOHANNA BATISTY METZA WOBEC KRYZYSU NAUKI SPOŁECZNEJ KOŚCIOŁA PO SOBORZE WATYKAŃSKIM II
}

\author{
S t r e s z c z e n i e
}

Teologowie okresu Soboru Watykańskiego II na kanwie teologii rzeczywistości ziemskich starali się usunąc rozłam, jaki panował między teologią i życiem, a także odpowiedzieć na kryzys nauki społecznej Kościoła w tamtym czasie. Szczególną rolę w tym kontekście odegrała teologia polityczna, której głównym przedstawicielem był J.B. Metz. Artykuł pokazuje i ocenia teologię polityczną jako nowy model nauki społecznej Kościoła.

Słowa kluczowe: teologia polityczna; Johann Batista Metz; Jürgen Moltmann; nauka społeczna Kościoła; Sobór Watykański II. 